\title{
Ontogenetic features of redox reactions in the myocardium of geese
}

Oleksandr Yakoviichuk ${ }^{1^{*}}$,

Olena Danchenko ${ }^{1}$,

Bohdan Kurtyak²,

Yulia Nikolaeva ${ }^{1}$,

Anastasia Fedorko',

Tetiana Halko ${ }^{1}$

${ }^{1}$ Bogdan Khmelnitskiy Melitopol

State Pedagogical University,

20 Getmanska St.,

Melitopol 72312, Ukraine

${ }^{2}$ Lviv National S. Z. Gzhytskyi University of Veterinary Medicine and Biotechnologies,

50 Pekarska St.,

Lviv 79010, Ukraine
Under conditions of physiological stress of different aetiologies, cells of any organism undergo compensatory metabolic changes. The specificity of such changes primarily depends on functional and histochemical features of the tissues of the body. The purpose of this work was to describe the functioning of the main components of the oxidation-reduction system, (ORS, the Krebs cycle, and the antioxidant system) in the myocardium of geese under conditions of the physiological stress occurring during the transition from the embryonic to postnatal development. It has been experimentally established that in the second half of geese embryogenesis, the content of short-chain fatty acids is significantly increased and the content of long-chain polyunsaturated fatty acids in their myocardium decreases. During the first two weeks of the postnatal period, there are reversible changes in the fatty acid composition of this tissue. The second half of the embryogenesis is characterized by the activation of dehydrogenases of the Krebs cycle in the low variability of antioxidant enzyme activity. At the same time, the experiment demonstrated an increase in the antioxidant activity coefficient, with the exception of its significant reduction on the first day of postnatal ontogenesis. The functioning of the ORS in the myocardium of geese is characterized by the presence of correlations between the nature of the changes of 19 investigated components (dehydrogenases of the Krebs cycle, antioxidant enzymes, lipid peroxidation products, antioxidant activity coefficient, fatty acids, their total content and unsaturation) and structuring of the system into two clusters.

Keywords: dehydrogenase, Krebs cycle, fatty acids, antioxidant protection, hyperoxia, hypoxia

\section{INTRODUCTION}

Each living organism is a biological system the functioning of which is ensured by a balanced flow of oxidation-reducing processes (Yakoviichuk et al., 2017). Under the conditions of physi-

\footnotetext{
*Corresponding author. Email: alex.yakov1991@gmail.com
}

ological stresses of different aetiology, this balance is dynamic and the cells undergometabolic alterations aimed at compensating for the harmful factor. The specificity of these alterations depends on functional and histochemical peculiarities of the tissue. The role of the major inducers of the metabolic transformation belongs to the active forms of oxygen (ROS). It is known that, on 
the one hand, the active forms of oxygenare important messengers in the transmission of cell signals and regulation of various body functions. On the other hand, they are able to intensify lipid peroxidation processes (Jung et al., 2017; Ortiz et al., 2017; Cortese-Krott et al., 2017). Each physiologically-stressful period is accompanied by intensification of peroxide oxidation of lipids; and the transition of geese from the hypoxia of embryonic development to the hyperoxia of postnatal one is characterized by a physiological stress (Danchenko et al., 2012; Zdorovtseva et al., 2012). The high content of polyunsaturated fatty acids (Fedorko et al., 2015), and their use as one of the main energy substrates of myocardium (Stanley et al., 2005) must provoke this involvement of the tissue redox system in the adaptation restructuring. Therefore, the aim of the work was to find out the peculiarities of the functioning of the main parts (the Krebs cycle and the antioxidant system) of the redox system in the myocardium of geese in the physiologically-stressed period of transition from the embryonic to the postnatal period of ontogenesis.

\section{MATERIALS AND METHODS}

In the experiment, the eggs of Kharkiv geese breed with the average mass of $145.7 \pm 2.62 \mathrm{~g}$ were used. The effectiveness of the Krebs cycle was evaluated by the activity of its dehydrogenases, and the effectiveness of the antioxidant system by the content of lipid peroxidation end products and antioxidant enzyme activity. At the same time, we determined the content of fatty acids in the examined tissues. The investigation of the dynamics of these indicators was performed during the second half of embryogenesis and postnatal adaptation at physiologically reasonable time (Ionov, 1997).

The activity level of dehydrogenases of the Krebs cycle was determined by the degree of reduction of potassium hexacyanoferrate (III) by using the incubation environment: succinate dehydrogenase (SD) (EC 1.3.5.1) (Eshchenko, Volsky, 1982), a-ketoglutarate dehydrogenase (2-OGD) (EC 1.2.4.2) (Gupta et al., 1980).
The activity of antioxidant enzymes was determined by the widely-used methods: superoxide dismutase (SOD) (EC 1.15.1.1) (Syrota, 2000), catalase (CAT) (EC 1.11.1.6) (Korolyuk et al., 1988), glutathione peroxidase (GPO) (EC 1.11.1.9) (Havrilova, Hmaraet et al., 1986).

The intensity of the peroxide processes was evaluated by the content of lipid oxidation end products (TBARC) in myocardium homogenate, and at the initiation of lipid peroxidation (LPO) by $\mathrm{Fe}^{2+}$ (TBARCi) (Ionov et al., 2011). Besides, antioxidant activity coefficient $\left(\mathrm{K}_{\mathrm{AOA}}\right)$ was used (Danchenko et al., 2012) as an integral indicator of AOP system state. The fatty acid content was determined by gas-liquid chromatography. Lipid extracts for the analysis were prepared by the Bligh and Dyer method (Bligh, Dyer, 1959), according to Palmer's recommendations (Palmer, 1971). In addition to the total content of unsaturated fatty acids (UFA) (zC), the total equivalent concentration of UFA relative to the double bonds (unsaturation, N) was calculated (Danchenko et al., 2012). Correlation and cluster analysis of the obtained results were undertaken by the known methods, their statistical processing was carried out using Microsoft Office Excel 2013 software package and SPSS v.13, with Student's t-test. If $p \leq 0.1$, the correlations were considered statistically significant; if $p \leq 0.2$, they were treated as tendencies to correlate. The cluster modelling was made in Diagram Designer v.1.28.

\section{RESULTS AND DISCUSSION}

During the embryonic developmental period (from day 22 of embryogenesis), the content of oleic (18:1), linoleic (18:2), and linolenic (18:3) acids increased significantly, while the content of long-chain polyunsaturated acids (arachidonic, docosopentaenoic and docosahexaenoic) decreased (Table). Transition to atmospheric respiration was characterized by a stable total level of UFA. At the same time, the unsaturation of FA from day 22 of embryogenesis to day 1 of the postnatal period decreased by $44.5 \%$, which is one of genetically 
Table. Content of fatty acids, products of lipid peroxidation, the enzyme activity of the Krebs cycle, and the AOP in geese myocardium $(M \pm m, n=5)$

\begin{tabular}{|c|c|c|c|c|c|c|}
\hline \multirow{3}{*}{ Indicator } & \multicolumn{6}{|c|}{ Age, days } \\
\hline & \multicolumn{4}{|c|}{ Embryogenesis } & \multicolumn{2}{|c|}{ Postnatal ontogenesis } \\
\hline & -15 & -8 & -2 & 0 & 7 & 14 \\
\hline \multicolumn{7}{|c|}{ Fatty acids } \\
\hline $16: 0, \%$ & - & $21.38 \pm 1.07$ & $24.24 \pm 1.21$ & $27.17 \pm 1.36$ & $22.58 \pm 1.13$ & $23.24 \pm 1.16$ \\
\hline $16: 1, \%$ & - & $1.13 \pm 0.06$ & $1.79 \pm 0.09^{*}$ & $1.91 \pm 0.1$ & $2.43 \pm 0.12^{\star}$ & $0.88 \pm 0.04^{*}$ \\
\hline $18: 0, \%$ & - & $14.15 \pm 0.03$ & $12.86 \pm 0.64$ & $11.5 \pm 0.58$ & $11.78 \pm 0.59$ & $18.58 \pm 0.93^{\star}$ \\
\hline $18: 1, \%$ & - & $24.84 \pm 1.24$ & $28.88 \pm 1.44^{\star}$ & $35.66 \pm 1.78^{\star}$ & $25.71 \pm 1.29^{*}$ & $22.82 \pm 1.14$ \\
\hline $18: 2, \%$ & - & $5.02 \pm 0.25$ & $6.72 \pm 0.34^{*}$ & $7.24 \pm 0.36$ & $15.72 \pm 0.79^{*}$ & $11.81 \pm 0.59^{\star}$ \\
\hline $18: 3, \%$ & - & $0.06 \pm 0.003$ & $0.11 \pm 0.01^{\star}$ & $0.14 \pm 0.01^{\star}$ & $0.91 \pm 0.05^{\star}$ & $0.72 \pm 0.04^{\star}$ \\
\hline $20: 4, \%$ & - & $14.43 \pm 0.72$ & $8.95 \pm 0.45^{\star}$ & $6.2 \pm 0.31^{\star}$ & $6.33 \pm 0.32$ & $7.75 \pm 0.39^{*}$ \\
\hline $22: 5, \%$ & - & $1.96 \pm 0.1$ & $0.61 \pm 0.03^{\star}$ & $0.57 \pm 0.03$ & $0.43 \pm 0.02^{\star}$ & $0.78 \pm 0.04^{\star}$ \\
\hline $22: 6, \%$ & - & $0.06 \pm 0.003$ & $0.05 \pm 0.003$ & $-^{*}$ & $0.08 \pm 0.01^{*}$ & $0.07 \pm 0.01$ \\
\hline $\begin{array}{c}\text { Total unsaturation, } \\
\mathrm{mol} / \mathrm{g}\end{array}$ & - & $0.349 \pm 0.02$ & $0.286 \pm 0.01$ & $0.277 \pm 0.01$ & $0.314 \pm 0.02$ & $0.291 \pm 0.02$ \\
\hline Content of UFA, $\%$ & - & $47.5 \pm 2.38$ & $47.11 \pm 2.36$ & $51.72 \pm 2.59$ & $51.61 \pm 2.58$ & $44.83 \pm 2.24$ \\
\hline \multicolumn{7}{|c|}{ Enzymes of the Krebs cycle } \\
\hline $\mathrm{SD}, \mathrm{nMol} / \mathrm{min}^{\star} \mathrm{g}$ & $24.7 \pm 2.0$ & $412.5 \pm 22.0^{*}$ & $504.2 \pm 6.0^{*}$ & $441.7 \pm 29.0$ & $557.5 \pm 23.0^{*}$ & $511 \pm 25.0$ \\
\hline $\begin{array}{c}\text { 2-OGD, } \\
\mathrm{nMol} / \mathrm{min}^{\star} \mathrm{g}\end{array}$ & $7.8 \pm 0.7$ & $29.17 \pm 0.6^{\star}$ & $56.1 \pm 1.4^{*}$ & $14.17 \pm 0.3^{\star}$ & $46.83 \pm 1.7^{\star}$ & $18.83 \pm 0.7^{\star}$ \\
\hline \multicolumn{7}{|c|}{ Enzymes of the AOP system } \\
\hline $\mathrm{GPO}, \mu \mathrm{Mol} / \mathrm{min}^{\star} \mathrm{g}$ & $16 \pm 0.4$ & $12 \pm 1.1^{\star}$ & $12 \pm 1.0$ & $21 \pm 1.3^{*}$ & $8 \pm 1.0^{*}$ & $13 \pm 1.0^{*}$ \\
\hline $\mathrm{CAT}, \mu \mathrm{Mol} / \mathrm{min}^{\star} \mathrm{g}$ & $44 \pm 1.7$ & $26 \pm 0.9^{\star}$ & $27 \pm 0.8$ & $33.5 \pm 1.7^{\star}$ & $19 \pm 0.9^{*}$ & $38 \pm 0.9^{\star}$ \\
\hline $\begin{array}{l}\text { SOD, cond. } \\
\text { units / } \min ^{\star} \mathrm{g}\end{array}$ & $41 \pm 0.8$ & $47.6 \pm 3.6$ & $37.1 \pm 2.7$ & $34.3 \pm 2.4$ & $26.7 \pm 0.8$ & $18.1 \pm 1.6^{*}$ \\
\hline \multicolumn{7}{|c|}{ Products of lipid peroxidation } \\
\hline TBARC, nMol/g & $14.1 \pm 0.6$ & $47.7 \pm 2.8^{*}$ & $33.5 \pm 1.3^{*}$ & $9.7 \pm 0.6^{*}$ & $20.1 \pm 0.4^{*}$ & $41.4 \pm 0.5^{\star}$ \\
\hline TBARCi, nMol/g & $32.9 \pm 1.7$ & $91.9 \pm 2.8^{\star}$ & $71.6 \pm 4.1^{\star}$ & $47.42 \pm 1^{\star}$ & $43.4 \pm 1.9$ & $48.9 \pm 0.4$ \\
\hline $\mathrm{K}_{\mathrm{AOA}}$ & 0.43 & 0.52 & 0.47 & 0.21 & 0.46 & 0.85 \\
\hline
\end{tabular}

Note. The difference is reliable in comparison with the previous indicator where: ${ }^{*}-p \leq 0.05$.

programmed mechanisms of tissue protection from the harmful influence of free radicals (Zdorovtseva et al., 2012) and is connected with the involvement of alternative systems of antioxidant protection (Euczaj et al., 2017), realization of which occurs by means of $\Delta-3$ and $\Delta$-6-desaturases activity reducing (Turner, Rooker, 2005; Lykova, 2012; Zdorovtseva et al., 2012).

During the second week of ontogenesis, inverse changes in the content of these acids were observed: the content of polyenoic long-chain acids (arachidonic and docosopentaenoic) increased and the content of essential linoleic and linolenic conversely reduced. However, the most significant changes in the unsaturation of FA were observed from day 22 to 28 of embryogenesis. That is genetically programmed preparation of the organisms of bird embryos for the hyperoxia of the late embryonic period. This leads to the decrease of lipids unsaturation of tissue and is connected to the involvement of alternative systems of antioxidant protection (Euczaj et al., 2017) and the intake of food 
substances that have antioxidant properties (Fedorko et al., 2015) and activate the AOP enzymes work (catalase and glutathione peroxidase by 100.0 and $62.5 \%$ ), that leads to the increase of $\mathrm{K}_{\mathrm{AOA}}$ (Table).

The activity of the dehydrogenases of the Krebs cycle increased during the second half of the embryonic development. This is the consequence of mitochondria differentiation and of the increase of cell energy needs (Kozlov et al., 1995). At the moment of transition to postnatal existence, 2-OGD is characterised by a significant decrease (by 3.96 times) in the activity that can be connected with the depletion of the initial substrate as a result of its involvement in alternative mechanisms of non-enzymatic neutralization of free radicals (Mailloux et al., 2009). The period of transition to lung respiration is physiologically stressed (Danchenko et al., 2012) and requires mobilization of the antioxidant system of the organism. Under these conditions, the decrease in the activity of 2-OGD may reduce the burden on the AOP system, since $\alpha$-ketoglutarate dehydrogenase is capable of generating superoxide and peroxide radicals (Nemeria et al., 2014; Quinlan et al., 2014). The known mechanisms of enzyme inhibition by the oxidation of cysteine residues of E3 subunit with free radicals, hydrogen peroxide (Sadek et al., 2002) and nitrosation with peroxynitrite and nitrogen oxide of tyrosine residues of E1 and E2 (Park et al., 1999; Tretter, Adam-Vizi, 2005). But the most likely variant is the influence of 4-hydroxy-2-nonenal on the lipoic acid in the E2 component of enzyme (Humphries, Szweda, 1998), because the content of TBARC during this period significantly increases (Table). In this case, 2-OGD is a marker of oxidative stress development (McLain et al., 2011). The increase in the enzyme activity in postnatal ontogenesis is probably the result of an organism's release from a physiologically stressed state (Tretter, Adam-Vizi, 2005), as indicated by the decrease in the activity of AOP enzymes and the increase of the AOA coefficient (Table). An additional reason for the increase of 2-OGD may be the intake of thiamine and calcium as part of feeds as they can stimulate the work of this enzyme (McCormack, Denton, 1979).

The embryonic development of geese occurs in hypoxic conditions (Danchenko et al., 2012). This is caused by the need for transcription with hypoxia-induced genes that facilitate the production of glycolytic ATP until oxygen delivery is improved (Chen et al., 2001). The regulation of cell sensitivity to oxygen is provided by transcription factors of the ARNT family. These factors include the HIF-1 $1 \alpha$ heterodimer, its biosynthesis is regulated by $\mathrm{O}_{2}$ availability (Piantadosi, Suliman, 2008). At the increase of the oxygen partial pressure, HIF-1 $\alpha$ is exposed to proteasomal degradation, the result of which is the conversion of a-ketoglutarate, succinate accumulation and accordingly SD activation at the end of embryonic development and the decrease of 2-OGD activity in early postembryonal development. The alternative mechanism for activating the enzyme may be its glutathionylation, since it is known about a significant increase of SD activity in the state acylated by glutathione (Quinlan et al., 2012). This process is aimed at decreasing the sensitivity of the enzyme to oxidative stress and is realized by the involvement of glutaredoxin-2 (Grx2) (Chen et al., 2007; Chen et al., 2008).

Activation and stabilisation of SD activity in postnatal ontogenesis can be caused by increasing the total flow of electrons through the respiratory chain in the background of the intake of a significant amount of various vitamins with the feedstuff. This procedure of activation is possible as the enzyme is a part of the second complex of the electron transfer chain (Quinlan et al., 2012).

On the first day of postnatal development, there was a significant activation of antioxidant enzymes CAT and GPO, which was caused by the influence of stress factors on the organism, in particular, the increase of partial pressure of oxygen, and, possibly, due to the accumulation of NADH and ATP (Tretter, Adam-Vizi, 2000), which are necessary for the functioning of protective systems of the organism (Lu, 1999). In 
the postnatal period, the activity of SOD decreased.

Correlation and cluster analyses were carried out to determine the existence and character of the integrated structure order of the interaction of investigated indicators. According to the results of this analysis, two clusters were obtained (Fig. 1).

Cluster-1 has a more complex structure (Fig. 1). The highest-ranking among the investigated indicators contains palmitic acid (16:0), which provides the internal integration of the systems due to the bonds with oleic (18:1) and docosahexaenoic (22:6) $(0.902 ; p \leq 0.05$ and $-0.883 ; p \leq 0.05)$ acids, and total unsaturation $(\mathrm{N})(-0.833 ; p \leq 0.1)$. The connection with the antioxidant protection system is provided by direct correlation (16:0) with glutathione peroxidase $(0.844 ; p \leq 0.1)$.

Among the indicators of the AOP system, $\mathrm{K}_{\mathrm{AOA}}$ has the highest rating, and it has four reliable connections. Connections with fatty acids are provided via stearic and oleic acids (0.932, $p \leq 0.05$ and $-0.877, p \leq 0.1)$, and through the total content of UFA $(-0.834 ; p \leq 0.1)$. Additionally, a direct correlation between the content of secondary lipid decomposition products after the initiation with $\mathrm{Fe}^{2+}$ (TBARCi) and polyunsaturated arachidonic and docosapentaenoic acids $(0.956 ; p \leq 0.05$ and $0.853 ; p \leq 0.1$ ) was established. Besides, these acids have direct connections with total unsaturation at the level (0.796-0.819 at $p \leq 0.1)$.

In accordance with cluster-2 (Fig. 2), close correlations between linoleic (18:2) and linolenic acids $(0.981 ; p \leq 0.01)$ were established within the tissue. Besides, integration with the Krebs cycle is provided by SD connections with 18:2 (0.867; $p \leq 0.1)$ and $18: 3(0.823 ; p \leq 0.1)$. Integration with $\mathrm{AOP}$ enzymatic system is realized by a negative $18: 3$ bond with superoxide dismutase $(-0.823 ; p \leq 0.1)$ and is also mediated through the CAT and SD connections $(-0.723$, $p \leq 0.1)$ and 2-OGD $(-0.818 ; p \leq 0.1)$.

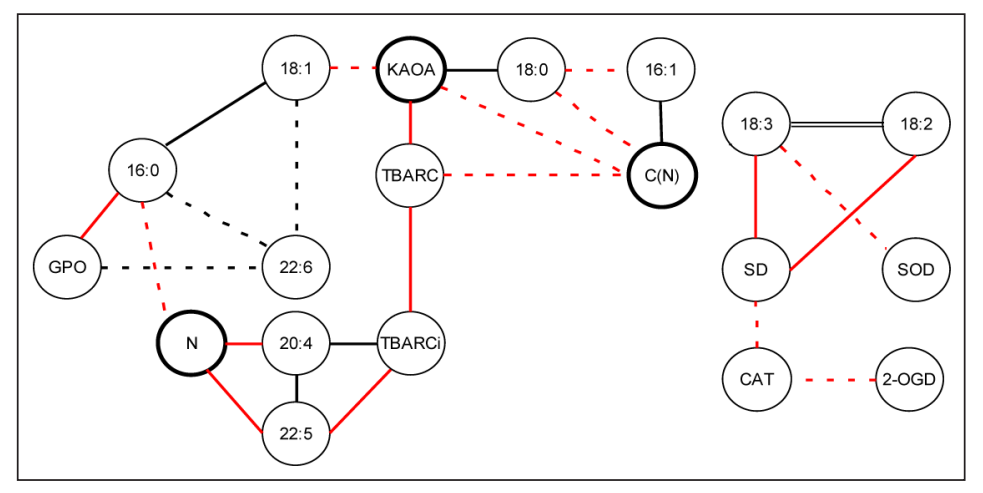

Fig. 1. Clusters of indicators of energy exchange, peroxide oxidation, and fatty acid content in geese myocardium: direct correlations are represented by solid lines $(r>0)$, the backward correlations in dotted lines $(r<0)$; double black lines - the level of correlation significance is $p \leq 0.01$; single black lines $-p \leq 0.05$; single red lines $-p \leq 0.1$

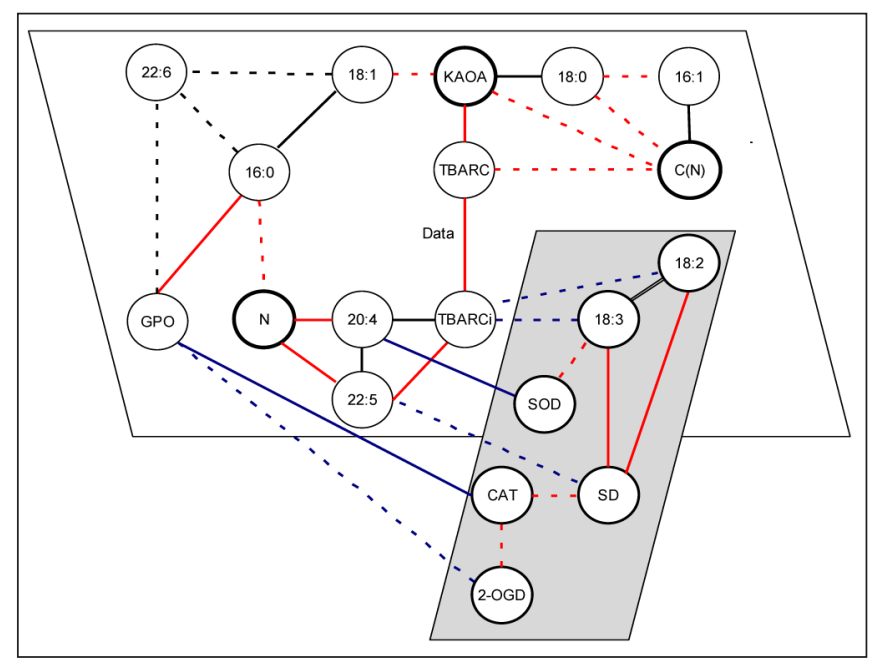

Fig. 2. Clusters of indicators of energy exchange, peroxide oxidation, and fatty acid content in geese myocardium: direct correlations are represented by solid lines $(r>0)$; backward correlations in dotted lines $(r<0)$; double black lines - the level of correlation significance is $p \leq 0.01$; single black lines $-p \leq 0.05$; single red lines $-p \leq 0.1$; single blue lines $-p \leq 0.2$ 


\section{CONCLUSIONS}

1. At the end of the embryogenesis, changes in the fatty acid composition of the geese myocardium are characterized by a decrease in longchain PUFA content (arachidonic, docosopentaenoic, and docosahexaenoic acids) against the background of a stable total content of unsaturated fatty acids. The unsaturation of the fatty acids in the embryonic period decreases (by $44.5 \%$ ), and in the postnatal period it gradually increases.

2. Against the background of various directed changes in the activity of investigated enzymes, the antioxidant activity $\left(\mathrm{K}_{\mathrm{AOA}}\right)$ in the transition to atmospheric breathing decreased by half. In the postnatal period, this indicator increased rapidly.

3. Correlation and cluster analyses of the tissues of the geese heart confirmed the existence of a single redox system, in which, depending on the state of the organism and the nature of the damaging factors, different mechanisms of the adaptive response with the predominant involvement of one or another of its components can be realised.

4. Direct and indirect connections of $\mathrm{K}_{\mathrm{AOA}}$ myocardium with the majority of unsaturated fatty acids content indicate that at this stage of development, with increased oxygen consumption, the regulation of lipid peroxidation becomes more important by means of triggering neurohumoral mechanisms that reduces unsaturation of fatty acids lipids and in this way they significantly increase cell resistance to harmful effects of oxygen active forms.

Received 27 June 2018 Accepted 2 November 2018

\section{References}

1. Havrilova AR, Hmara NV. Determination of the activity of glutathione peroxidase of erythrocytes at saturated concentrations of the substrate. Laboratory case 1986; 12: 721-4. Russian.
2. Eshchenko ND, Volsky GG. Determination of the amount of succinic acid and succinate dehydrogenase activity. In: Methods of biochemical research. Leningrad: Leningrad State University. 1982; 207-12. Russian.

3. Ionov IA. The physiological status of the bird in embryogenesis and postnatal ontogenesis, depending on their $\mathrm{A}, \mathrm{E}$ and $\mathrm{K}$-vitamin content. Extended abstract of Doctor's thesis. Harkiv 1997. Ukrainian.

4. Kazimirko VK, Maltsev VI. Functions of unsaturated fatty acids in the body. Health of Ukraine. 2004: 95: 38-46. Russian.

5. Lykova IO. Changes in the fatty acid composition of lipids in the tissues of various organs of the sandpipers during the pre-migration period. Brant. 2012; 15: 95-102. Ukrainian.

6. Korolyuk MA, Ivanova LI, Mayorova IT. Method for determination of catalase activity. Laboratory case. 1988; 1: 16-9. Russian.

7. Danchenko OO, Pashhenko YuP, Danchenko NM, Zdorovceva LM. Mechanisms of support prooxidant-antioxidant balance in the liver tissues of geese in hypo- and hyperoxia. Ukr Biochem J. 2012; 84(6): 109-14. Ukrainian.

8. Kozlov VA, Tverdokhleb YV, Shpon'ka YS, My'shalov VD. The morphology of the developing heart (structure, ultrastructure, metabolism). Dnepropetrovsk: Dnipropetrovsk State Medical Academy; 1995. Russian.

9. Determination of malondialdehyde in tissues and organs. In: Ionov IA, Shapovalov SO, Rudenko EV, Long MN, Akhtyrsky AV, Zozulya YuA, Komisova TE, Kostyuk IA. Criteria and methods of control. Kharkov: Institute of Animal Husbandry of the National Academy of Agrarian Sciences of Ukraine. 2011; 224-5. Russian.

10. Yakoviichuk OV, Danchenko TO, Ruban GV, Fedorko AS, Nikolayeva YuV. Main features of maintaining balance of redox reactions in the tissues of geese in late embryonic and early postnatal period of the ontogenesis. Bulletin of the Zaporizhzhya National University. Biological sciences. 2017; 1: 106-15. Ukrainian. 
11. Syrota TV. 2000. Russian Federation Patent No. 99103192/14. Russian.

12. Mailloux RJ, Singh R, Brewer G, Auger C, Lemire J, Appanna VD. Alpha-ketoglutarate dehydrogenase and glutamate dehydrogenase work in tandem to modulate the antioxidant alpha-ketoglutarate during oxidative stress in Pseudomonas fluorescens. J Bacteriol. 2009; 191(12): 3804-10.

13. Bligh EG, Dyer WJ. A rapid method of total lipid extraction and purification. Can J Biochem Physiol. 1959; 37(8): 911-7.

14. Fedorko AS, Danchenko OO, Nikolaeva YV, Yakoviychuk AV. Fatty acid composition of tissue lipids in goslings and goose embryos. The Animal Biology. 2015; 17(1): 132-9.

15. Gupta SC, Dekker EE. Evidence for the identity and some comparative properties of alphaketoglutarate and 2-keto-4-hydroxyglutarate dehydrogenase. J Biol Chem. 1980; 255(3): 1107-12.

16. Nemeria NS, Ambrus A, Patel H, Gerfen G, Adam-Vizi V, Tretter L, Zhou J, Wang J, Jordan F. Human 2-oxoglutarate dehydrogenase complex E1 component forms a thiamin-derived radical by aerobic oxidation of the enamine intermediate. J Biol Chem. 2014; 289(43): 29859-73.

17. Humphries KM, Szweda LI. Selective inactivation of alpha-ketoglutarate dehydrogenase and pyruvate dehydrogenase: reaction of lipoic acid with 4-hydroxy-2-nonenal. Biochemistry. 1998; 37(45): 15835-41.

18. Jung KA, Lee S, Kwak MK. NFE2L2/NRF2 activity is linked to mitochondria and AMPactivated protein kinase signaling in cancers through miR-181c/mitochondria-encoded cytochrome coxidase regulation. Antioxid Redox Signal. 2017; 27(13): 945-61.

19. Łuczaj W, Gęgotek A, Skrzydlewska E. Antioxidants and HNE in redox homeostasis. Free Radic Biol Med. 2017; 111: 87-101.

20. Lu SC. Regulation of hepatic glutathione synthesis: current concepts and controversies. FASEB J. 1999; 13(10): 1169-83.
21. McLain AL, Szweda PA, Szweda LI. a-Ketoglutarate dehydrogenase: a mitochondrial redox sensor. Free Radic Res. 2011; 45(1): 29-36.

22. Park LC, Zhang H, Sheu KF, Calingasan NY, Kristal BS, Lindsay JG, Gibson GE. Metabolic impairment induces oxidative stress, compromises inflammatory responses and inactivates a key mitochondrial enzyme in microglia. J Neurochem. 1999; 72(5): 1948-58.

23. McCormack JG, Denton RM. The effects of calcium ions and adenine nucleotides on the activity of pig heart 2-oxoglutarate dehydrogenase complex. Biochem J. 1979; 180(3): 533-44.

24. Quinlan CL, Orr AL, Perevoshchikova IV, Treberg JR, Ackrell BA, Brand MD. Mitochondrial complex II can generate reactive oxygen species at high rates in both the forward and reverse reactions. J Biol Chem. 2012; 287(32): 27255-64.

25. Chen YR, Chen CL, Pfeiffer DR, Zweier JL. Mitochondrial Complex II in the Post-Ischemic Heart: Oxidative Injury and the Role of Protein S-glutathionylation. J Biol Chem. 2007; 282(45): 32640-54.

26. Ortiz GG, Pacheco Moisés FP, MirelesRamírez M, Flores-Alvarado LJ, GonzálezUsigli H, Sánchez-González VJ, SánchezLópez AL, Sánchez-Romero L, Díaz-Barba EI, Santoscoy-Gutiérrez JF, Rivero-Moragrega P. Oxidative stress: love and hate history in central nervous system. Adv Protein Chem Struct Biol. 2017; 108: 1-31.

27. Palmer FB. The extraction of acidic phospholipids in organic solvent mixtures containing water. Biochim Biophys Acta. 1971; 231(1): 134-44.

28. Piantadosi CA, Suliman HB. Transcriptional regulation of SDHa flavoprotein by nuclear respiratory factor-1 prevents pseudo-hypoxia in aerobic cardiac cells. J Biol Chem. 2008: 283(16): 10967-77.

29. Chen CL, Chen J, Rawale S, Varadharaj S, Kaumaya PP, Zweier JL, Chen YR. Protein tyrosine nitration of the flavin subunit is associated 
with oxidative modification of mitochondrial complex II in the post-ischemic myocardium. J Biol Chem. 2008; 283(41): 27991-8003.

30. Chen C, Pore N, Behrooz A, Ismail-Beigi F, Maity A. Regulation of glut $1 \mathrm{mRNA}$ by hypoxia-inducible factor- 1 interaction between $\mathrm{H}$-ras and hypoxia. J Biol Chem. 2001; 276(12): 9519-25.

31. Sadek HA, Humphries KM, Szweda PA, Szweda LI. Selective inactivation of redox-sensitive mitochondrial enzymes during cardiac reperfusion. Arch Biochem Biophys. 2002; 406: $222-8$.

32. Stanley WC, Recchia FA, Lopaschuk GD. Myocardial substrate metabolism in the normal and failing heart. Physiol Rev. 2005; 85(3): 1093-129.

33. Quinlan CL, Goncalves RL, Hey-Mogensen M, Yadava N, Bunik VI, Brand MD. The 2-oxoacid dehydrogenase complexes in mitochondria can produce superoxide/hydrogen peroxide at much higher rates than complex I. J Biol Chem. 2014; 289(12): 8312-25.

34. Cortese-Krott MM, Koning A, Kuhnle GC, Nagy P, Bianco CL, Pasch A, Wink DA, Fukuto JM, Jackson AA, van Goor H, Olson KR, Feelisch $\mathrm{M}$. The reactive species interactome: evolutionary emergence, biological significance, and opportunities for redox metabolomics and personalized medicine. Antioxid Redox Signal. 2017; 27(10): 684-712.

35. Tretter L, Adam-Vizi V. Alpha-ketoglutarate dehydrogenase: a target and generator of oxidative stress. Philos Trans R Soc Lond B Biol Sci. 2005; 360: 2335-45.

36. Tretter L, Adam-Vizi V. Inhibition of Krebs cycle enzymes by hydrogen peroxide: A key role of [alpha]-ketoglutarate dehydrogenase in limiting NADH production under oxidative stress. J Neurosci. 2000; 20(24): 8972-9.

37. Turner JP, Rooker JR. Effect of diet on fatty acid compositions in Sciaenopsocellatus. Journal of fish biology. 2005; 67: 1119-38.

38. Zdorovtseva LM, Khromishev VO, Danchenko OO. Geese fatty acid composition of brain and heart lipids in hypo-and hyperoxia. Biological Bulletin. 2012; 2(3): 9-18 [in Ukrainian].

\section{Oleksandr Yakoviichuk, Olena Danchenko, Bohdan Kurtyak, Yulia Nikolaeva, Anastasia Fedorko, Tetiana Halko}

\section{OKSIDACIJOS IR REDUKCIJOS ONTOGENI- NĖS SAVYBĖS ŽĄSIES MIOKARDE}

\section{Santrauka}

Kiekvieno organizmo ląstelès skirtingu priežasčių fiziologinio streso sąlygomis patiria kompensacinius metabolinius pokyčius, kurių specifiškumas priklauso nuo funkcinių ir histocheminių kūno audinių savybių. Šio darbo tikslas - apibūdinti pagrindinių oksidacijos ir redukcijos sistemos (ORS, Krebso ciklas ir antioksidacijos sistema) komponentų funkcionavimą žąsies miokarde skirtingomis fiziologinio streso sąlygomis embriono vystymosi iki postnatalinio periodo metu. Eksperimentiškai nustatyta, kad antrame žąsies embriogenezès periodo etape labai padidejja trumpujų grandžiu riebalų rūgščių kiekis ir sumažejja ilgụjų grandinių polinesočiụjų riebalų rūgščių kiekis miokarde. Per pirmąsias dvi postnatalinio periodo savaites ịvyksta grįžtamieji riebalų rūgščiu sudèties pokyčiai. Antrajame embriogenezės etape, esant mažam antioksidantinių fermentų aktyvumui, vyksta Krebso dehidrogenazių aktyvacija. Kartu pastebètas antioksidantinio aktyvumo koeficiento padidejimas, išskyrus reikšmingą jo sumažejimą pirmają postnatalinès ontogenezės dieną. ORS veikimas žąsies miokarde charakterizuojamas pagal koreliaciją tarp 19 ištirtų komponentų (Krebso dehidrogenazès, antioksidantinių fermentų, lipidų peroksidacijos produktų, antioksidantinio aktyvumo koeficiento, riebalų rūgščių, jų bendro kiekio ir neprisotinimo) ir sistemos struktūrizavimosi ị dvi grupes.

Raktažodžiai: dehidrogenazė, Krebso ciklas, riebalų rūgštys, antioksidantinè apsauga, hiperoksija, hipoksija 